\title{
English as Foreign Language (EFL) Teacher's Questioning Strategies in Classroom Interaction
}

\author{
Nashruddin Nashruddin ${ }^{1} \&$ Putri Rahmawati Ningtyas ${ }^{2}$ \\ ${ }^{1}$ STKIP Muhammadiyah Barru. Barru. Indonesia \\ ${ }^{2}$ STKIP Dampal Selatan. Toli-Toli. Indonesia \\ putrilantera@gmail.com
}

\section{ARTICLE HISTORY \\ Received : 2020-02-27 \\ Revised : 2020-03-03 \\ Accepted : 2020-03-25}

\section{KEYWORDS}

Questioning Strategies Types of the Questions Classroom Interaction

\begin{abstract}
The objectives of this research were to find out the teacher's questioning strategies, types of the questions, and the reasons of using the questioning strategies in classroom interaction.. This qualitative research using discourse analysis approach. The sample of this study was a teacher of SMPN 1 Tanete Riaja, Barru Regency Data collection of this research was conducted through recording, observation, and interview. The data collected were analyzed through conversational analysis that was used in analyzing teacher's questioning strategies, types of the teacher's questions, and the reasons for using questioning strategies in EFL classroom. The research findings showed that the teacher used questioning strategies by applying some types of questions. The open/ closed questions and knowledge questions were used dominantly by the teacher. It depends on the material that the teacher transferred to the students. Otherwise, synthesis and evaluation questions were used only a few times by teacher. The teacher also applied some strategies, namely questioning in the opening session, questioning in the middle of teaching, prompting the questions, probing the question, and gave reinforcement to the students. The research finding indicated the positive effects of questioning strategies which were applied by the teachers toward EFL Classroom. It was proved by the students' participation in learning. Moreover, it was shown by the observation sheets that the teacher and all students did a good interaction teaching-learning process.
\end{abstract}

\section{Introduction}

Classroom management is an important aspect of teacher's competence to create teaching-learning effectively. It focuses on a teacher's ability to plan and deliver the lessons, and to control the students' behaviors. Harmer (2007) states that the effectiveness of the teaching and the learning activities depends on how teacher directs, guides, inspires, facilitates and controls the student to participate in learning activities. If the management of classroom is not effective, it can disrupt the teaching-learning process in classroom.

One of ways that can be used to direct, guide, inspire, and control the students' participation in learning activities is asking or giving question, which is called questioning. Questioning to students must be applied in questioning strategies. Questioning strategies are the ways which are used to ask something to the students in gaining a purpose in teaching. In teaching learning process, the teachers need to know the ability of the students and how far the students understand the material which has been taught.
Questioning is a process that always occurs in a process of communication, including in learning process. Questioning skill is an expression or question that is uttered by teacher as a stimulus to emerge the responds from learners (Cotton, 1989). For teachers, questioning skill is a very important skill to master. It is because, through this skill, teacher can create the learning situation more meaningful. According to Cotton (1989), the learning process will be very dull, if the teacher explains the materials in hours without interspaced with questions, either just provocation question, or analysis question.

The success of TEFL in the classroom refers to the application of questioning strategies by the teachers. According to Halstead and Mclaughlin (1999), question is one of the most important tools in guiding and extending students' learning. It can help the teachers to develop their own strategy to enhance the students work and thinking. Recent research on questioning in teaching English based on teacher's questioning strategies in the classroom interaction. Paule (2002) states the tendency for teachers to ask many questions has been observed in much investigation. 
Questioning strategies used by teacher can stimulate students to be more involved in language learning process. Teacher's questioning strategies must be applied because it is one of the factors that can produce an effective process of teaching and learning. Questioning must be applied in a good manner as a teaching device. It requires knowledge about types of question, questioning strategies, and reasons for questioning skill. Therefore, the aims of this research are to investigate what types of questions that the teacher uses, how teacher applies questioning strategies, and the teacher's reason in questioning.

\section{Review of Literature}

Question is a sentence, phrase, or gesture that seeks information through a reply. It means that questions are expressions said by a person which are needed to answer by the listener. Some definition of this term is proposed by some experts. According to Brown (2000) question is any statement which tests or creates knowledge in the learner. In the teachinglearning process, teacher asks question in order that students learn, it means that they get knowledge or information, and improve their thinking ability. Paule (2002) argued that question is a sentence produced by a person to other person that involves command and interrogative expression to get any information or responses means a question.

Long and Sato (1983) state that question is a linguistic expression used to make a request for information. So, the information requested maybe provided in the form of an answer. Cotton (1989) defines question as any sentence which has an interrogative form or function. In classroom settings, teacher's questions are defined as instructional cues or stimuli. Teacher's questions deliver the subjects that will be learned to students, give directions about what they are going to do and how to do it. Questioning is a universally used activation technique in teaching, mainly within the Initiation-Response-Feedback pattern.

Note that teacher questions are not always realized by interrogatives. For example, the question: "What can you see in this picture?" may be expressed by the statement: "We'll describe what is going on in this picture.", or by the command "Tell me what you can see in this picture". So perhaps a question, in the context of teaching, may be best defined as a teacher utterance which has the objective of eliciting an oral response from the learners.

All educators, no matter what level, need to be able to craft and create at least the basic types of questions. There are some types of questions that teachers can use in teaching. Based on the research conducted by Bardovi-Harlig, Mossman, and Vellenga (2014) it was found that, based on the grammatical form, there are two types of questions; closed questions and open questions. Closed question is question that requires yes/ no answer. Open question is a type of question that needs wider information or answers. This type uses question words, such as what, why, where, when, why, and how.

Based on the objective of the question, the major types of questions fall into four categories, namely managerial, rhetorical, closed, and open question (Breen \& Candlin, 1987). Managerial questions are questions which keep the classroom operations moving; rhetorical questions used to emphasize a point or to reinforce an idea or statement; closed questions used to check retention or to focus thinking on a particular point; and open questions used to promote discussion or student interaction.

Educators have traditionally classified questions according to Bloom's Taxonomy (Marzano, Pickering, \& Pollock, 2001) covers six categories, namely:

a) Knowledge - recall data or information

Knowledge question or memory question is a question that wants students to know or remember again the material that had been learned. Question words that can be used in this type of question are: who, what, where, when, and mention.

b) Comprehension - understand meaning or organization and selection of facts and ideas

Comprehension question is a question that asks students to evidence that they have got enough comprehension in organizing the materials they have learned. Question words that can be used in this type of question are: elaborate, describe, compare or mention the difference, explain you're your own words.

c) Application - use a concept in a new situation.

This type of question does not simply require the ability to remember the theory, concept, or formula that has been learned, but needs more the ability to apply the theory, concept, or formula in solving a problem. Example: Write down the sentence below by using the correct capitalization!

d) Analysis - separate concepts into parts; distinguish between facts and inferences.

Analysis question is a question that wants students to think critically and deeply. In responding the analysis question, students consider the information to get a conclusion, and find evidences that can be used in conclusion. Example: What is the character of the main figure in the story you had read?

e) Synthesis - combine parts to form new meaning

Synthesis question is a high level question. This question demands students to think creatively 
from the teacher's question. The correct answer demands students to solve a problem. Example: What is the appropriate title for the passage below?

f) Evaluation - make judgments about the value of ideas or products

As like the analysis and synthesis question, evaluation question seeks higher thinking process. Evaluation question does not have only one correct answer. However, students are asked to give assessment or conception toward a problem. Example: What do you think about ...?

According to Gaither (2008) questioning strategy is one of the most important dimensions of teaching and learning. It gives tutors the chance to find out what students know and understand, and it allows students to seek clarification and help. It means that through questioning, teachers are able to know what the students know and what they do not know. Questions help teachers and learners in teaching learning process.

Chang (2009) explained that questioning techniques cover:

\section{a) Pausing}

After teacher gives a question, students are asked to be quite for a moment. It aims to:

$>$ give students chance to think the answer

$>$ get a complete answer

$>$ understand or analyze the question

$>$ make many students can answer

\section{b) Prompting}

Perhaps the teacher asks a difficult question, so no students can answer, or the question is unclear. Furthermore, the teacher should do "prompting". The ways are:

$>$ Giving additional information in order that students can answer

$>$ Changing the question in another form

$>$ Breaking the former question become some subquestions, so that, finally all questions can be answered.

\section{c) Probing}

Probing is tracking, guiding, or directing. Probing is conducted because the satisfying answer has not got yet. To find the complete answer, teacher appoints another student to answer. If the answer is still incomplete, teacher asks another else. Finally, the complete answer can be found.

There are many reasons why teachers should give some questions to their students, either the questions are addressed to individual student or the whole class in their classroom. According to Winnie (1994), teachers used various questions and questioning types as their strategy in questioning not only to promote classroom interaction, but also to encourage the students to communicate in a real-life setting, to build a closer connection with the students, and to help the students deal with difficulty in expressing themselves because of their limited vocabulary. The questions are used frequently at the end of the lesson but sometime at the beginning and the middle of teaching and learning process.

Different researchers provide various reasons way teachers give questions to students in classroom interaction. For example, Gaither (2008) proposes two reasons why teachers ask questions in their classrooms. First, questions require responses. Therefore, they serve a means of obliging learners to contribute to the interactions. Learner's responses also provide the teachers with feedback which can be used to adjust content and expression in subsequent teacher-talk. Second, questions serve a device for controlling the progress of the interaction through which a lesson is enacted. It has been found that questions can also be used to motivate students, to revise, control, test or assess, explore, explain, encourage students to focus on a particular topic, elicit information, and check understanding and to control behavior. It means that teacher's questions are not only a means of obliging teacher-talk to guide the students' attention but also adjudge students to be more active and focus on particular topic, so teachers can check and control the students' understanding.

The art of asking questions is an ancient part of good teaching and one of the rudimentary skills all teachers should be able to master. Knowledge and awareness are intrinsic part of each learner. In their research, Boopathiraj and Chellamani (2013) found that teachers applies questioning in the beginning or opening session of lesson, the middle of the teaching, and in the final session. Their research also indicated that teacher's question is one of important tools to extend students' knowledge. It can help teachers develop their own strategies to enhance the students' work and thinking.

According to Nashruddin, Ningtyas, and Ekamurti (2018) from the result of their research, teachers ask questions for a variety of purposes, including:

- To greet all students in the class

- To actively involve students in the lesson

- To find out something from the learners (facts, ideas, opinions)

- To increase motivation or interest

- To evaluate students' preparation

- To check on completion of work

- To develop critical thinking skills 
- To review previous lessons

- To assess comprehension or mastery of goals

- To stimulate independent learning

Through a classroom action research, Nashruddin and Roslina (2019) found that teachers use the questioning strategies as:

a) Reinforcement

The instructor should reinforce student responses and questions in a positive way in order to encourage future participation. The instructor can reinforce by making positive statements and using positive nonverbal communication.

b) Redirecting to Another Student

When teacher asks a question to a student and the student cannot answer the question, or the question is incorrect, the teacher may ask the question to other students. The teacher can call the name of particular student, or ask the student who can answer to raise his or her hand.

\section{c) Adjust/ Refocus}

When a student provides a response that appears out of context, the instructor can refocus to encourage the student to tie her response to the content being discussed. This technique is also used to shift attention to a new topic.

Cambridge International Dictionary of English defines the verb 'to interact' as 'to communicate with or react to each other'. The Oxford Dictionary of English defines the noun 'interaction' as a 'reciprocal action or influence'. Therefore interaction is more than action followed by reaction (Lewis \& Hill, 1992). According to Smith (2012), classroom interaction is the patterns of verbal and non-verbal communication and the types of social relationship which occur within classroom. The study of classroom interaction may be a part of studies of classroom discourse, teacher talk and second language acquisition. Unal and Unal (2012) stated that classroom interaction covers classroom behaviors such as turn taking, questioning and answering, negotiating of meaning and feedback.

\section{Method}

This research applied qualitative method especially conversation analysis. Strauss and Corbin (1990) claimed that qualitative methods can be used to better understand any phenomenon about which little is yet known. In line with that opinion, Bogdan and Biklen (2007) stated that qualitative research uses a naturalistic approach that seeks to understand phenomena in context-specific settings. About the conversation analysis (CA), Hyland and Paltridge (2011) stated that it is the study of talk-in-interaction, and it is a theoretically and methodologically distinctive approach to understanding social life.
The research subject was an English teacher of senior high school students at SMPN 1 Tanete Riaja, Barru. The teacher was chosen because she produces various kinds of questioning strategies in teaching and learning process. The data were collected in three steps namely knowing the schedule, observing the teaching and learning process, and interview. Furthermore, the data were analized into three steps namely data reduction, data display, and draw conclusion based on the theory of Miles and Huberman (1994).

The instruments that were used in collecting data are classroom observation list, audio recorder, and interview. To examine the questioning strategies distribution, the researcher took data recording by using recorder and followed the teaching learning process in the classroom. The data from recording was transcribed into written transform, and then been identified, selected, and also classified or extracted based on the analyzing needs which are relevant to the topic of this research. The transcription was analyzed by using questioning strategies analysis. Interview was used in gaining the more information about questioning strategies which were used by the teachers.

\section{Findings and Discussions}

In this research, researchers found that the teacher used some strategies in questioning to the students. The strategies are:

\subsection{The teacher questioned the students in opening sessions of teaching}

The teacher questioned the students in the opening session or starting the class. In this situation, the teacher asked all students to greet them. It can be seen in the following extract and the analysis.

Table 1. The $1^{\text {st }}$ Extract: Greeting Students

S: Assalamualaikum warohmatullohiwabarokatuh!

[Peace be upon you, and Allah's mercy and blessings]

T: Waalaikumussalam warohmatullohiwabarokatuh. How are you?

[May the peace, mercy, and blessings of Allah be with you too]

S: Fine!!!

T: Fine! Okay.

Analysis of the $1^{\text {st }}$ Extract: In the above extract, the teacher asked students in the opening session of teaching by saying "How are you?".The teacher used open question. This question was used by the teacher to greet all students. That was the strategy to start the class. All students answered that they were fine at the time. 
Table 2. The 2 ${ }^{\text {nd }}$ Extract: Asking about Students' Preparation

T: And, question for you. Did you sleep well last night?

S: Yes!!!

$\mathrm{T}$ : Of course. If you slept well, then you are ready to begin our lesson. (Smiling). Are you ready?

S: Yes!!!

Analysis of the $2^{\text {nd }}$ Extract: This situation showed the teacher asked all students to get the class ready.

Table 2 shows the teacher asked students, "Did you sleep well last night?". All students answered by saying "Yes". After that, she questioned again by saying, "Are you ready?". The teacher asked those questions to evaluate students' preparation to start the lesson. All students answered, "Yes!!!". It meant that they were ready to start the lesson.

\subsection{The teacher questioned the students in the Middle of the Teaching}

The teacher used this strategy to know the students' understanding about the materials that were learnt. Examples can be seen in the following extract and the analysis.

The teacher asked question to students to know whether they understand the lesson that had been explained before.

Table 3. The $3^{\text {rd }}$ Extract: Asking about the Lesson Material

T: Well! Descriptive Text (Pausing). In the last meeting we discussed about descriptive text. What is the function of descriptive text? (Pausing) Let's first be back. In the last lesson, ee.... [In the last meeting] we talked about descriptive text, and .... you had learned about how we describe something.

S: Me, Mam. Descriptive text .... We describe things ..... and, person.

T: Excellent! Descriptive text is a kind of text to describe a thing, an object, ....

Analysis of the $3^{\text {rd }}$ Extract: After one student answered that in previous meeting they learned about descriptive text, the teacher then asked to students what the function of descriptive text. Because all students did not respond, the teacher then gave additional information. Finally, one student answered the teacher's question. In addition, because the student's response is correct, the teacher then gave reinforcement by saying, "Yup! Excellent! Descriptive text is a kind of text to describe a thing, an object, or a person".
Table 4. The $4^{\text {th }}$ Extract: Asking to find out facts or ideas from the students

T: In this lesson, [In this meeting] I want you to be able to perform, yah, in front of the class, how to describe things. And the thing is the newspaper. Yah! Okay, ee....before we come in to the aa... lesson, I would like to invite some of you to come forward to write down some words related to newspaper. OK..... Here...., this one, newspaper, (writing the word of newspaper in the whiteboard). Please, come four students forward four students to write some words related to the newspaper! [Please, four students come forward to write four words related to newspaper!]. Yeah, one student in the back seat, could you try?

(One boy student came forward and wrote 'News stand' in the whiteboard).

Analysis of the $4^{\text {th }}$ Extract: The teacher commanded students to write some words related to the topic of the lesson.

Table 4 shows that the teacher asked the students to find out facts, or ideas from them by saying, "I would like to invite some of you to come forward to write down some words related to newspaper". It also shows that the teacher managed the circulation of question-answer, because she did not demand all students to answer together, but she started from a student who sat in the back seat.

\subsection{The teacher used prompting strategy, repeated the question in different or the same sentence.}

When the teacher asked a question and no students could answer, she repeated her question or gave additional information to help students in answering her questions.

Table 5. The $5^{\text {th }}$ Extract: Asking to Assess Students' Comprehension

T: Yeah, thank you very much. So, we have got four words related to...., to newspaper. Do you know the meaning of each word?

S: Yeees!!!

T: Okay. Irma, What is the meaning of Newspaper boy?

A girl student who was appointed did not answer.

$\mathrm{T}$ : Newspaper boy is a person who delivers or sells newspaper. Yaah, ee.... either boys or girls, then we can say, or we can call her a newspaper boy.

\section{S: Penjual koran!!!}

T: Ya....penjual koran, atau loper koran,....... tukang koran. 
In this situation, the teacher asked students to evidence that they had got enough comprehension in organizing the material that was learned.

Analysis of the $5^{\text {th }}$ Extract: In above table, it is shown that the teacher asked one student what newspaper meant. Because the student could not answer, the teacher then gave additional information by saying, "Newspaper boy is a person who delivers or sells newspaper". It was to help the student thinking about the meaning of the word asked. This strategy is called prompting strategy. Finally, the student could answer that newspaper boy is penjual koran.

Table 6. The $6^{\text {th }}$ Extract: Asking Students to Make Sentence

T: Is there still student to add using the word newspaper boy? Somebody want to add?

(All studentskept silent)

T: Who can make another sentence by using the word of newspaper boy?

S: Newspaper boy deliver the newspaper by bike.

T: Ouyaah! Newspaper boy delivers the newspaper by bike. Not by taxi, (All students laughed), because it is so expensive. (All students more laughed)

The teacher repeated her question to students by different sentence to make they can answer the question easily.

Analysis of the $6^{\text {th }}$ Extract: In the table 6, we can see the teacher repeated her question in different sentence. In the first time, she said, "Is there still student to add using the word newspaper boy? Somebody want to add?'.After that she asked again by saying, "Who can make another sentence by using the word of newspaper boy?". After a student answered, she gave reinforcement by a little joke, "Ouyaah! Newspaper boy delivers the newspaper by bike, not by taxi, because it is so expensive". She also corrected the student's ungrammatical sentence.

\subsection{The teacher used probing strategy}

Probing was conducted by the teacher because the satisfying answer had not got yet. To find the complete answer, the teacher appointed another student to answer.

Table 7. The $7^{\text {th }}$ Extract: Asking Students about Word Meaning

T: Hasan, what is the Indonesian word for headline?

$\mathrm{S}$ : Headline is judul berita

$\mathrm{T}$ : Good....mmm.... Hilda, do you agree with Hasan?

S: No, Mam. Headline itu .... berita utama.

T: Iyaa .... Berita utama. Very good. Thank you.
The teacher asked her question to one student. Because the student could not respond or the respond was incorrect, the teacher then redirected her question to another student.

Analysis of the $7^{\text {th }}$ Extract: Table 7 shows that firstly, the teacher asked to a student who was named Hasan by saying, "What is the Indonesian word for headline?". The Hasan's respond was incorrect, the teacher then asked to another student, namely Irma, and she answered correctly. That was the probing strategy. In addition, the teacher gave reinforcement.

\subsection{The teacher gave reinforcement for students who answered the questions correctly}

Table 8. The $8^{\text {th }}$ Extract: Asking for Students' Comprehension

$\mathrm{T}$ : What do people usually buy in a news stand?

S: Newspaper.

T: Okay. Clarissa, do you think it's that simple? Only newspaper?

S: Ee....аnu Mam. The News stand also sells magazines.

T: Okay, very good. News stand also sells magazine. Very good! Because in news stand, we don't only buy, ee.... newspaper, but we can also buy magazine.

After a student responded incorrectly, the teacher then redirected her question to another student.

Analysis of the $8^{\text {th }}$ Extract: In the above table, we can see that the teacher used probing strategy in questioning for students. All students said that news stand only sells newspaper. The teacher then asked to one student, Clarissa, to get satisfying response. She asked, "Clarissa, do you think it's that simple? Only newspaper?". The mentioned student answered that news stand also sold magazine. After that, the teacher gave reinforcement to her by repeating the sentence and corrected the grammar of the sentence.

\section{Conclusion}

This research described the use of questioning strategies in classroom interaction. It was found that the teacher applied more than one type of questions. Open/ closed questions were applied frequently in all session of teaching. Based on the research findings, the teacher sometimes repeated her question to clarify the sense of the question when she found difficulties on students in understanding the question. It can be concluded that the aims of using questioning strategies as a teaching device can be reached by doing and applying the questioning strategies in a good and appropriate way. It makes the interaction and communication between teacher and students more valuable. 
In this research, the researcher recommends to apply some questioning strategies in all section in teaching such as applied open/ close question, recall in the beginning, referential in the beginning or the final of teaching, or display after explaining the lesson or during task working, and other types of question in EFL classroom. Furthermore, the questioning strategies should be applied based on the lesson and the level of students to make the learning process run well.

\section{References}

Bardovi-Harlig, K., Mossman, S., \& Vellenga, H. E. (2014). The effect of instruction on pragmatic routines in academic discussion. Language Teaching Research, 19(3), 324-350. doi: $10.1177 / 1362168814541739$

Bogdan, R. C., \& Biklen, S. K. (2007). Qualitative Research for Education: An Introduction to Theories and Methods. Boston: Pearson Allyn \& Bacon.

Boopathiraj, C., \& Chellamani, K. (2013). Analysis of Test Items on Difficulty Level and Discrimination Index in the Test for Research in Education. International Journal of Social Science \& Interdisciplinary Research, 2(2), 189193.

Breen, M., \& Candlin, C. (1987). Which materials? A consumers' and designers' guide. In L. Sheldon (Ed.), ELT Textbooks and Materials: Problems in Evaluation and Development (ELT Documents). London: Modern English Publications.

Brown, H. D. (2000). Principles of Language Learning and Teaching. New York: Longman.

Chang, M. (2009). Learning Culture and Language through ICTs: Methods for Enhanced Instruction. London: Information Science Reference.

Cotton, K. (1989). Classroom Questioning. from http://www.nwrel.org/scpd/sirs/3/cu5.html

Gaither, J. F. (2008). Questioning techniques: Research-based strategies teachers. from http://thesecondprinciple.com/teachingessential/five-basic-types-questions

Halstead, J. M., \& Mclaughlin, T. H. (1999). Education in Morality. London: Routledge.

Harmer, J. (2007). The Practice of English Language Teaching (3rd ed.). New York: Longman.

Hyland, K., \& Paltridge, B. (2011). Continuum Companion to Discourse Analysis. New York: Continuum International Publishing Group.
Lewis, M., \& Hill, J. (1992). Practical Techniques for Language Teaching. Cambridge: Cambridge University Press.

Long, M. H., \& Sato, C. J. (1983). Classroom Foreigner Talk Discourse: Forms and Functions of Teachers' Questions. In H. W. Selinger \& M. H. Long (Eds.), Classroom Oriented Research in Second Language Acquisition. Rowley, Mass: Newbury House.

Marzano, R., Pickering, D., \& Pollock, J. (2001). Classroom instruction that works: Researchbased strategies for increasing student achievement. Alexandria, VA: Association for Supervision and Curriculum Development.

Miles, M. B., \& Huberman, A. M. (1994). Qualitative Data Analysis: An Expanded Sourcebook (2nd ed.). Thousand Oaks CA: Sage Publication.

Nashruddin, N., Ningtyas, P. R., \& Ekamurti, N. (2018). Increasing The Students'motivation In Reading English Materials Through Task-Based Learning (Tbl) Strategy (A Classroom Action Research at the First Year Students of SMP Dirgantara Makassar). Scolae: Journal of Pedagogy, 1(1), 44-53.

Nashruddin, N., \& Roslina, R. (2019). Pemberian tugas terstruktur untuk meningkatkan hasil belajar matematika siswa kelas xi smk. Histogram: Jurnal Pendidikan Matematika, 3(1), 1-13.

Paule, M. (2002). Classroom questioning in English. Teacher Tools, 2(2), 127-131.

Smith, R. C. (2012). Situational Language Teaching. ELT Journal, 2(4), 71-79.

Strauss, A., \& Corbin, J. (1990). Basics of Qualitative Research: Grounded Theory Procedures and Techniques. Newbury Park: Sage Publications, Inc.

Unal, Z., \& Unal, A. (2012). The Impact of Years of Teaching Experience on the Classroom Management Approaches of Elementary School Teacher. International Journal of Instruction, 5(2), 41-60.

Winnie, P. H. (1994). International Encyclopedia of Education, Student Cognition in Learning from Teaching. Oxford: Postlewaite T. (Pergamon, UK). 